\title{
Deciphering Economic Futures: Electricity, Calculation, and the Power Economy, 1880-1930
}

\author{
Daniela Russ \\ In: Centaurus (forthcoming)
}

\section{Introduction $^{1}$}

A few years after Emil Rathenau's death, the economic journalist Felix Pinner wrote a laudatory biography placing the engineer squarely into his century. In Emil Rathenau und das elektrische Zeitalter (1918), Pinner portrayed Rathenau as the true inventor of the concept of the central station, the large-scale, centralised generation of electricity for a variety of urban consumers. Echoing a common prejudice against early American electro-technical engineering, Pinner noted that Edison's Pearl Street Station missed the "systematic design", it was a "purely empirical" power station, a result of experimentation and little calculation. In The Electric Review, Edison had played down the role of mathematicians in developing his electric system and Pinner contrasted this self-portrait with the calculating mind of the engineer-entrepreneur: Rathenau's creativity and imagination ventured beyond the limits of the present, too, "but he let mathematicians search the paths into the future before entering them." In Pinner's almost Hegelian account, Edison built the first central station, but Rathenau grasped and realised the concept of the central station - the concept in which the electric age comes to itself. ${ }^{2}$

Such teleological reading of its history was widespread in the electro-technical industry at the time, as was the obsession with great 'captains of industry' such as Rathenau (the biography appeared as a volume in Wilhelm Ostwald's series Great Men: Studies in the Biology of Genius). But what makes Pinner's observations interesting for today's historians of technology and this Special Issue is his emphasis of the conceptual, ideal moment in electrical development: According to Pinner, calculation and theorising (referred to as 'codification' in the introduction) helped Rathenau realise the potential for electrical development, a potential which is always already immanent in produced electricity, but which cannot be seen without translating the operation of a central station into numbers and studying them. Mathematics, in this view, is a tool to decipher potentialities and go beyond what is: The manager who operates power stations in a strictly empirical way, registering only the demand that already exists, will always be bound to the past; the manager who strives for a systematic design, studying the relations between the system's components, will begin to form the demand the system requires.

Pinner's observations were of course anachronistic. Edison's experimental approach was hardly only a matter of character or genius, but a way to enter technically and commercially uncharted territory. Rathenau could take up the economic opportunity of Edison's electric lighting system, only once Edison and the Menlo Park engineers (and mathematicians!) had invented it. Their approaches reflect not only different personalities, but differences in electric development. Pinner's emphasis on the concept of central stations was no less rooted in its time: Between the construction of Edison's Pearl Street Station in 1881 and Rathenau's death in 1915, it had indeed become impossible to design

\footnotetext{
${ }^{1}$ Research for this article was funded by the Histoire de Comité d'Éléctricité et d'Énergie, Fondation Éléctricité de France. I want to thank the participants of the 'Latent, Present Energy' workshop in Berne, three anonymous reviewers and the editors of this Special Issue for their feedback on earlier versions of this article.

2 Pinner (1918, pp. 130-131), all translation from the German and Russian by the author.
} 
or manage stations without relating them to principles of electric development. Over that period, economic calculations had become a vital part of the construction of electrical power systems and engineers routinely drew on the relations between capacity, load, and unit costs, they had learned in their training and in handbooks on central station design. Indeed, Rathenau's son Walther and other second generation power engineers had by then turned to the systematic design of a much larger object- the national power economy- the sphere where a nation's power was produced, distributed, and consumed.

Scholars have approached these calculating practices largely from the point of view of the history of electricity and electrical engineering. In Thomas Hughes' account of the evolution of large technological systems, central station systems acquired momentum - mass, velocity, and direction between the 1890s and the First World War. They did so by the sheer amount of capital invested in the machines and devices, by the business interest representing this capital, and by the birth and organization of an electric engineering profession. ${ }^{3}$ In this view, concepts such as the load factor can be understood as a common point of reference for technicians and managers working in the same industry. Studies generally underline the role of central station theory for the institutionalization and expansion of the industry as well. ${ }^{4}$ While this is true, these studies treat electricity as an industry among others whose history can be told independently from each other. Seen from the broader history of energy, these approaches miss the significance of electrical systems for how the relations between power, industry, and society, could be visualized and imagined in a new way. As I argue in this paper, the calculations around electricity assume a broader meaning in the early twentieth century: They can be seen as a medium in which a new relation between energy and society is imagined.

To clarify what I mean by 'medium', let's look at Timothy Mitchell's account of colonial governance in Egypt, in which he describes a new mode of representing economic life. He points out how governing from the distance required a lens through which a simplified representation of economic exchanges could be drawn. This lens was often a commodity considered sufficiently central to express in its movements all other economic movements: grain or cotton, and finally, when no single commodity could stand for the diversity of economic exchanges, money. According to Mitchell, money and cotton are neither tools to make something visible that already existed nor two representations of the same economy (the flow of cotton will show a moneyless economy; the monetary economy abstracts from all commodities such as cotton). They are different modes of representation, constituting different ways in which object and representation relate to each other. In other words, monetary accounting and today's concept of 'the economy' appear together: the economy constitutes and is constituted as the sphere of monetary movement. ${ }^{5}$

Mitchell dates the emergence of 'the economy' to the period after the Second World War. Historical scholarship supports the view that there was no developed system of macroeconomic statistics before the interwar years. The calculations around an autonomous economic sphere-measures of national income, balance of payment, unemployment, indexes of prices and productivity — only appeared at the time. ${ }^{6}$ At the margins of economics was still room for alternative economic imaginations: There were the neoliberals, who were sceptical of the political governance of economic life through macroeconomic knowledge ${ }^{7}$ and the engineer-economists, who emphasised the material

${ }^{4}$ Stier (1999), Hannah (1979), Coopersmith (1992), Lagendijk (2009).

${ }^{4}$ Stier (1999), Hannah (1979), Coopersmith (1992), Lagendijk (2009).

${ }^{5}$ Mitchell (2002, pp. 80-119).

${ }^{6}$ Tooze (2001).

${ }^{7}$ Slobodian (2018). 
basis and sought to extent the 'rational' organisation of their technical systems to that of the world economy. While neoclassical economists built the repertoire of macroeconomic statistics we are familiar with today, and neoliberals gave up on statistics all together, the engineer-economists built their economics partly on the calculations around electrical systems. By then, these spanned entire regions, integrated different power plants and supplied a wide variety of consumers.

This contribution traces how power becomes a mode of economic representation in the early twentieth century. Power as a representation would mean that there is a phenomenon (electricity) and then there is a calculation that corresponds to it, adding nothing to it. By speaking of a mode of representation, I want to highlight that 'power' imposes an order on electricity, which is not its own. First, measuring an object "means to change it into another form of being," begins to stand in new (quantitative) relations. Second, approaching electricity as 'power' means to conceive of it as one source of mechanical power, the technical equivalent of labour power with a potential to bring about economic change (instead of a source of lighting or heat, for instance). Third, this order leaves the phenomenon itself not untouched, it goes into the very constitution of electricity: When electricity is seen as power, it affects the design of electrical systems, which and how certain parts of society are electrified.

The paper proceeds as follows. As I will show in the first part, controlled currents can only be realised within a technical system, which is necessarily based on some measurement and calculation of how current, voltage, and resistance relate to each other. This constant technical 'mediation' of electricity makes it into a particular homogeneous form of energy. The second part explores how engineers and managers appropriated controlled currents for commercial means and how an economics of central stations emerged in the 1890s. From then on, considerations of capital costs and future revenue went more and more into the construction of central stations and their expansion into power systems. I argue that this is not an economic perspective on a natural or physical phenomenon - economic calculations go into its very constitution as a physical object. The third part shows that with power systems, this economic perspective is no longer limited to the business itself, but expands to regions, nations, and the world economy. In the medium of the power economy, engineers, economists, and politicians imagine the relation between the national and the world economy, between technical progress and the nascent macroeconomic object of 'the economy'. Studying this discourse through the papers presented at the World Power Conferences, I distinguish two ways in which calculations around electricity become relevant for economic policy: as an indicator of economic growth and as the ground for a new economy.

\section{Controlling Currents}

Historians of technology have pointed out the breaks, inconsistencies, and contingencies in the electro-technical development from the first lighting systems and isolated stations to the interconnected power systems of the 1920s and 1930s. ${ }^{9}$ Thomas Hughes has emphasized the agency in this process by speaking of system-builders. ${ }^{10}$ From the point of view of the history of energy, I want to suggest a slightly different reading that pays more attention to the materiality such a system works with. I understand electrical systems as appropriations: they are the results of work that shapes the materiality of electricity in a way that it fulfils an economic purpose. However, electricity does

\footnotetext{
${ }^{8}$ Cassirer (1953, pp. 188-189).

${ }^{9}$ Coopersmith (1992, 1993, 2004); Hughes (1993; 1976); Passer (1953); Hannah (1979; 1995).

${ }^{10}$ Hughes (1979).
} 
not exist in nature in a way that would allow to simply seize or enclose it, it has to be properly produced.

Early experiences of natural electricity prior to its artificial generation were rare and scattered. While charged amber and lightning were both commonly observed, the two were not recognized as related phenomena. Only the experimental scientists of the seventeenth and eighteenth century showed them to be linked by the processes of electrical charge and discharge, and in so doing redefined both concept and practice of electricity. These early modern experimental scientists anticipated the operators of electrical stations centuries later. For both, electricity was handled as an electrotechnical fact, a conceptualization evident well before the construction of modern 'large technological systems.' Electric utilities do not exploit, refine, and supply a resource, but rather create it: the appropriation of electricity hinges on the technical production of controllable currents. The technical is a precondition; it reaches into the very constitution of the phenomenon. Electricity requires constant, uninterrupted work in a manner coal, petroleum and gas do not. ${ }^{11}$

This technical containment of electricity is crucial for its appropriation by the system-builders. At a time when there was still no reliable classification of coal, this constant technical mediation made electricity into a particularly universal and flexible good. "Whereas [coal and petroleum] are limited in their circulation and application by all kinds of local and individual conditions," predicted a book on electricity for the broader public in 1893, "electricity will achieve a universal validation comparable to gold; as a certain unit of electricity is the same here as in America and Australia." 12 Once currents were controlled, electricity was homogeneous like steam; once large-scale transmission was mastered, the use of power became less dependent on specific places. By reviving water power and making use of a larger variety of fuels, electricity brought about a new landscape of industrial production.

Electrical systems required a higher degree of calculation, as well as instruments of control and documentation. In contrast to oil, coal, and gas, electrical power cannot be separated from its infrastructure; it is this infrastructure. The potential for electric power only exists as a voltage, a certain relation between two points of a circuit. Even before the work of the system-builders, electrical current could be realized and controlled only within a technical system (see Turnbull, this issue). In that sense, the early isolated stations supplying arc lights or electromotors were systems, too: a structure of related components where every part could affect the whole to the degree of a failure of the entire system. This is also why a certain level of calculation and some control devices were needed to realize a continuing electrical current in the first place: there is a quantitative relation between the capacity of the generator and the number of the arc lights or capacity of an electric motor that has to be considered before building the system. The matching of supply and demand an economic principle in the oil and petroleum industries - is a technical requirement in electrical systems.

The technical system does not coincide with the economic system of electricity. From the physical point of view, electrical current denotes the (closed) circulation of electrons. Thus, strictly speaking, the water or steam turbine driving the generator is not part of the technical system of controlled currents. This limit can be meaningful for economic calculations, for instance, when an electric lighting system is integrated in a factory, which already generates electricity (i.e. when the installation of the boiler and generator is not part of the investment). As a rule, however, the boiler, and above

${ }^{11}$ Heilbron (1982); Stichweh (1988).

12 Wilke (1893, p. 633). 
all the turbine, are important parts of the economic system of electricity, as they determine to a large part the capacity, efficiency, and cost of the overall system. Thomas Hughes limits the electric system to these components, as they are under the control of system-builders. He is right that neither the designing engineers nor the managers control consumption directly. In utilities such as Edison's central station, however, the level and type of consumption become vital sources of information, which can turn a functioning system into an economic failure. Indeed, Hughes himself described how system design and management reacted to customer load. ${ }^{13} \mathrm{~A}$ history of the modes of representation broadens this understanding of the technical-economic system by including the information on production and consumption, insofar as it is documented or can influence the system in any another way.

The isolated stations dominating electrical development until the early twentieth century relied mainly on the relation between current, voltage, and resistance to control currents for commercial purposes. The lamps acted as resistances in the circuit, so that their number followed from the current and voltage the generator was able to maintain. In the early 1880s, the components of this system were tightly coupled, few very bright lamps were connected in series and could not be separately controlled (in the early Siemens system, each generator lighted only one lamp). Even when new types of generators and lamps allowed for a somewhat better 'divisibility' of electric light, its brightness limited it to industry, streets or large public buildings, unlike the more flexible gas lighting. As electricity was sold per contract (which specified the light-hours), there was no inherent motive to expand the system and create demand. ${ }^{14}$

Hughes' system-builders were not the first to appropriate currents, but they transformed the isolated electric lighting systems into electric utilities. In Edison's incandescent lighting system the components began to depend on each other in a new way, which went beyond the fitting of voltage, current and resistance. In this system, electricity was centrally supplied, and customers could control their lamps independently, which caused a variation in power demand that was captured by meters. These systems obeyed to the same technical principles of electrical circuits and in addition brought about new economic relations between the system and customers, as well as among customers. The 'systematic' design Pinner had in mind - large turbines, transmission lines, and a diversity of urban customers - referred to these new economic relations in public utilities that were far from selfevident. Early central stations managers struggled with high capital costs and fluctuating demand, sometimes to the point of entrepreneurial failure.

Edison's central station pioneered electric power supply as an industry of its own. The electric industry was international from its beginning: Engineers and entrepreneurs presented new inventions and sold their patents to an international audience at the annual International Electrotechnical Exhibitions and the World Fair. The first generation of electrical engineers - trained in machinebuilding or other fields of engineering - often gathered in special sections of older engineering organizations before founding their own institutions. The discussion around central station design and profitability took place in these institutions, as well as in the journals they founded over the 1880s. In the following years, a discourse on the economics of central stations and electricity

\footnotetext{
${ }^{13}$ Hughes (1993, p. 7).

14 This holds true for isolated stations in the industry as well. Here they were part of the overall economic system of a factory or business, which owned and operated them for their own use. Questions of technical design were connected to questions of business management: the overall cost of the system, its advantages over gas lighting, and the potential efficiency gains. As electricity constituted one cost factor of a product or service in these systems, factory managers tended to pursue a strategy of reducing its costs.
} 
emerged in trade journals, industrial associations, and on international conferences. ${ }^{15}$ The economic future of the central station was still open.

\section{The Electric Power Industry, International Finance and Central Station Management}

Over the following decades, central stations became technically and economically more complex. Three wire systems, alternating current, and transformers, made the supply of larger areas possible, yet also posed new problems to control the system's current, load, and voltage. Central stations introduced switchboards and other control devices, but also sought ways to govern the economic state of the system through tariffs, meters, and electrical appliances (see Schädler, this issue). This expansion and large-scale production setting off in the 1890 s came as a surprise to many in the central station business. Edison himself had envisioned a more conservative system of bloc stations with small and flexible machinery that could adapt to fluctuations of the load. According to the memories of Oskar von Miller, then president of the German Edison Company, Edison asked in face of the large machinery employed in the Berlin central stations in 1891 how much money every machine made in one revolution and Miller proudly responded, "8 Mark 30 Pfennig for every rev!"16 With long-distance transmission lines and powerful steam turbines, an ever-cheaper supply would encourage demand and shape the load it needed.

Companies spawned new companies in the electric power industry. While the earliest electrical companies were in the field of manufacturing, central stations gave rise to operating and, later, financial holding companies. These types of companies were often nested in or related to each other. For instance, Edison had set up the Compagnie Continentale Edison of Paris to market his system in Europe. After the International Electrotechnical Exhibition in Paris in 1881, several European firms or entrepreneurs - among them Emil Rathenau - purchased the rights to manufacture and market Edison's patents in their home countries. The companies acquiring these rights were often experienced in electrical manufacturing and hoped to create a new market for their products by venturing into the central station business. They established new companies to plan and operate central stations, while the parent company would manufacture and supply the equipment. When central stations became larger and more capital-intensive in the 1890s, financial institutions and holding companies specializing in the financing of electrical development formed. ${ }^{17}$

Such patent and marketing relations fostered international standardization and exchange, but harmonized station design only to a certain extent. The central stations operating in Europe in the 1880s were very diverse in their design; some ran on alternating current (AC), others on direct current (DC), ${ }^{18}$ they differed in the size and type of boilers and generators employed, in the organization of system control, in the structure of their consumers (usually a combination of arc lamps and incandescent lamps), and in the way they charged them (by meter or contract). It was still disputed whether, and how, central stations could be profitably managed. Engineers were aware of

\footnotetext{
${ }^{15}$ See for the discussions in Elektrotechnische Zeitschrift (est. 1880), the Electrical Review (est. 1882), the Journal of the Institution of Electrical Engineers (est. 1889), La Lumière Électrique (est. 1879), and the Electric Age (est. 1890).

16 Miller (1906, p. 616).

17 Passer (1953); Hausman, Hertner \& Wilkins (2008).

18 Alternating or direct current was one of the most important differences in systems design, as it affected almost all other components, as well as the layout of the system. DC systems have a stable electric field and electrons flowing in the same direction, while in AC systems the field oscillates, and electrons change their direction. Only alternating current allows for an easy transformation of voltages — a fact which made it more suitable for larger systems, in which higher voltage electricity was used for distribution, which was then transformed down in the place of utilization.
} 
the many varieties of electrical development, they discussed them in publications, and sought international standardization beyond these differences. ${ }^{19}$

Central station service shared the problem of other capital-intensive undertakings: it had to account for and earn the cost of its fixed capital. In the early years, this problem was solved pragmatically, by way of trial-and-error, or using common commercial principles. Voltage or load diagrams - the voltage or power recorded over a certain stretch of time - were used for technical purposes, to control and regulate the system and minimize its waste. Following the economics of gas works, the distinction of fixed and operational costs was widely used but its relation to rate making was not paid much attention (i.e. consumers were not charged for their share of fixed costs). Particularly in Europe, where gas works and electric power stations often passed over into municipal ownership after a couple of decades, profitability was only one part of a larger equation, which also included a reliable and affordable supply.

With larger systems, capital costs rose, too. Alternating current, large steam turbines, and highvoltage transmission allowed for an expansion of electrical systems from a couple of hundred meters to several kilometres around the turn of the century. To finance and coordinate these projects, manufacturing companies and banks set up intermediary companies in a joined effort to finance electric development. While the precise structure of these intermediaries varied (from holding companies in the US to the German Unternehmergeschäft), their task was to create and finance, sometimes in cooperation, electric supply utilities. Planning the project and supervising the construction of the plant, these holding companies retreated and put their shares of the subsidiary company on the market as soon as their purpose was fulfilled and the electric companies were able to share dividends regularly. ${ }^{20}$ Mostly occupied with financing, these companies later also set up technical sections to plan and supervise their projects and ensure their economic success.

The standardization of accounting around central stations has to be seen in this context of financing. One of the earliest formal cost analyses of electric service was conducted by John Hopkinson, a famous British electrical engineer, and J. A. Fleming at the London Holborn Viaduct station in 1882. Even though the station kept running losses and closed a couple of years later, Hopkinson continued working on the economics of central stations and pioneered the formalizations around the load factor - the power supplied over a period of time in relation to maximum capacity. Debates on the rate of depreciation, the unit of charge (lamp-hours or $\mathrm{kWh}$ ), the ratio of fixed to operational costs, and the construction of a rate system reflecting these relations, became more intense over the $1890 \mathrm{~s}^{21}$ The load factor is a straightforward measure of capital utilization. The first formalizations, presenting a general relation between load and unit cost of electricity, appeared at the turn of the century. The idea was that by flattening the curve at a high level, a maximum utilization of the fixed capital could be achieved. By that time, there were handbooks on central station service explaining the relations between unit costs, load, and rate making. ${ }^{22}$

\footnotetext{
${ }^{19}$ See for an early overview and comparison of stations, Forbes (1889); see on the discussion of profitability, Meyer (1895, p. 26); see on the IEC, Büthe (2010).

20 Segreto (1994, p. 164). Holding companies have forerunners in the financing of gas works and railways, see Paquier (2001). Edison cooperated with J. P. Morgan while Siemens and AEG joint forces with Swiss banks to establish Elektrobank and Indelec. The US-American system of holding companies differed insofar as the holding company kept controlling shares in the operating companies, Lambert (2015, p. Chap. 1).

${ }^{21}$ Hughes (1993, p. 57). See for the debate around capital costs and accounting in central stations, Hopkinson (1915); Haas (1895, pp. 121-122); Müllendorf (1894).

${ }^{22}$ Merz \& McLellan (1904); Siegel (1906); Klingenberg (1913, 1914, 1920); and Insull (1915).
} 
[Fig. 1: Klingenberg, Georg (1913): Bau großer Elektrizitätskraftwerke. Berlin: Springer, p. 26]

[Fig: 2a: Klingenberg, Georg (1913): Bau großer Elektrizitätskraftwerke. Berlin: Springer, p. 10]

[Fig: 2b: Klingenberg, Georg (1913): Bau großer Elektrizitätskraftwerke. Berlin: Springer, p. 10]

Load management articulated not only the current state of the system but also its potential futures, and operators pursued strategies of expansion and intensification on the basis of it. The first graph (Fig. 1), taken from a popular textbook on central station service written by AEG's head of plant construction, shows the change in unit costs with an increasing load factor, thus expressing potential savings. In the same textbook, the author shows two typical load curves (Fig. 2a, 2b), indicating how the industrial power load can fill the gap between the two peaks of lighting load in the early morning and evening. Samuel Insull's management at the Chicago Edison Company is the most well-known example of how electricity can be appropriated to make profits via load management. Insull researched the urban economy through the data of his power system, he made a typology of urban consumers according to their load profiles, and even formalised their influence on the system's load in a diversity factor, a ratio indicating each group of customer's contribution to the system's peak (the peak sets the capacity the station has to provide at any time independent of actual demand). While not all managers pushed cost accounting to this extreme, load management became a regular part of central station service in the first decades of the twentieth century. It can be seen as a mode of representation, generating the distinction of an urban economy absorbing electric power, and the central station recording it. ${ }^{23}$

[Fig. 3: Insull, Samuel (1915): Central-station electric service; its commercial development and economic significance as set forth in the public addresses (1897-1914) of Samuel Insull, Chicago, p. 450.]

This type of electric system spread to cities around the globe through foreign direct investments of the large American and European electric power companies and imperial states. At the same time, states radicalised the tendencies of an expanded and intensified energy use. The war accelerated the integration of the industrial and urban systems into larger, regional systems. During the war, some governments forced industrial stations into a common grid to control power supply and visions of a large, unified systems of power supply flourished. In the post-war time, the systems that were seen as most rational and most advanced combined multiple power plants, urban and industrial load, and supplied several cities of a region. As has been shown, the planners of these large systems applied the principles which had been developed in central station service tp the larger level of the regional or national power grid. ${ }^{24}$

\section{III. 'The Power Medium of the Nation': Electricity and the Search for Economic Order}

After the war, the economic and financial order in which the power industry had risen was in shambles. Money was devalued, currencies could no longer be converted, and some foreign

\footnotetext{
${ }^{23}$ Hughes (1979, 1993, Chapter VIII); Platt (1991); Insull \& Keily (1915, p. 448); see on the diversity factor in general Cravath (1915).

${ }^{24}$ Hughes (1993, pp. 324-403), Hausman et al. (2008, pp. 127-8), Lagendijk (2009, p. 47). See Gilson (1996) on Georg Klingenberg and the German debate on a centralised power system; see Hughes (1976) for the US American discussion on 'giant power'.
} 
investments had been nationalised or taken over by third parties. This loss of capital, investment and markets affected the European corporations more than their US counterpart, but a call for remaking this order was prevalent everywhere in the industry. At the same time, governments realised that state power had become utterly dependent on the supply of fuel and electricity and engineers had moved into positions of public service. ${ }^{25}$ In this situation, the power economy served as a medium in which both politicians and engineers expressed their visions of how production and money, national and world economy should be related. Power was no longer merely a matter of business or industry, but of politics and economics.

This broader perspective reflected the real size and structure of the electric power business, which had outgrown the bounds of any single industry. Not only had it become more and more concentrated, but it also touched on more and more industries. "Electricity is not an industry," noted Walther Rathenau, Emil Rathenau's son and heir of the AEG, in 1909, "but a complex of industry, a sphere of the economy. It includes lighting and power, transport undertakings, the machine tool industry, the steam engine industry, centralisation and decentralisation of the production and distribution of power, and it links up with nearly all the other well-known fields of industry today. ${ }^{\circ 26}$ By means of its entanglement with many other businesses, this 'complex of industry' touched on political matters and was interested in the economic and political world order on which their undertakings depended. As representatives of the corporations controlling the flows of power, electric power engineers reached managerial and public positions. ${ }^{27}$

The engineers formed their identity and positions against 'traditional' politics and economics. Within corporations, they found themselves trapped between material and monetary efficiency and sought to overcome the dilemma by a scientific management that would extend the engineer's calculation to financial matters. Within the larger world order, their magnificent apparatuses of production depended on the flow of capital, access to markets, and the supply of raw material —all of which was precarious during and after the war. Just like the business accountant hampered the technical perfection of which engineers were capable within the corporation, politicians and financial managers impeded the realization of rational production at the scale of the world or nation-state. ${ }^{28}$ Contemporaries noted this "growing consciousness of an essential difference in outlook and interest between the engineer and those who control the application of his abilities" in the rise of conferences, journals, and publications in which engineers pondered on the world order. ${ }^{29}$

This frustration was particularly strong among power engineers, who understood themselves as spearheading technical progress. The World Power Conference (WPC) grew out of this dismay. As

\footnotetext{
${ }^{25}$ Hausman et al. (2008, pp. 127-42), Cherp \& Jewell (2011, p. 202), Tooze (2015), Meer (2012).

${ }^{26}$ Cited in Joll (1960, p.73).

${ }^{27}$ To mention just two examples from Germany and the US: Walther Rathenau became head of the organization coordinating raw material allocation during the First World War (and minister of foreign affairs after the war), while General Electric's Owen D. Young became part of the Business Cycle Committee set up by president Hoover in 1922 . In 1931, Gerard Swope (then director of General Electric) presented a plan for recovery that was widely discussed and influenced New Deal policies, see Hawley (1966, p. 41), Özgöde (2015, p. 91).

28 Stabile (1986, pp. 44-45), Akin (1977). Scholars have mostly focused on the Technocracy Movement in the US-on Frederick Taylor, Howard Scott, and Thorstein Veblen. However, the roots of this technocratic thinking are more generally linked to industrial societies and the positions of engineers in corporations than a superficial focus on these American authors might suggest, see Russ \& Turnbull (2021).

${ }^{29}$ Thomas (1935, pp. 589-90). Apart from the public writings of engineers, such as Hugh Quigley's 'Electrical Power and National Progress' (1925), Wichard von Moellendorf's 'Deutsche Gemeinwirtschaft', and Walther Rathenau's many works, new journals discussed the relation between politics and technology, see for instance 'Technik und Wirtschaft' published by the Verein deutscher Ingenieure and the shorter-lived 'World Survey' by the World Power Conference.
} 
president of a lobby organization of the British electric power industry, Daniel Dunlop gathered engineers, politicians, and entrepreneurs for a first conference in London in 1924. While participants generally had stakes in the power economy, Dunlop intended a broader economic angle-indeed, he had first wanted to set up a world economic body - that would highlight energy as a world-economic matter. ${ }^{30}$ The conference assembled an audience that shared Dunlop's conviction that energy had become the most important factor of modern economic life, but the session exploring this relation was still comparatively small and overwhelmingly British and US American: The president of the US Chamber of Commerce stated that "power consumption is the most direct reflection of human progress." And Herbert Hoover, striking a somewhat more anthropological note, called electrical energy "the greatest tool that has ever come into the hands of men." 31 These two statements roughly reflect the two ways in which the power economy was appropriated in the economic policy of the interwar years: as an index to track economic growth, or as the ground on which a new economy could be built.

During the economic crises that followed the war, economists flocked into a field that sought to understand the regularity of economic booms and busts. Over the 1920s, institutes for business cycle research or Konjunkturforschung popped up in several countries. While there had been attempts to understand 'economic rhythms' before, conjuncture and business cycle research can be seen as a response to the shattered economic institutions after the war. From the perspective of the national governments, it constituted a way to understand the relation between the supply of money and goods through statistics of prices and production. From the perspective of businesses, it was seen as a way to discern order from and adapt to the chaos of the world economy. One of the earliest contributions to the theory of trade cycles comes from a Swedish electrical engineer in public office, Axel Enström, who was also a delegate to the World Power Conference. ${ }^{32}$ In business cycle research, economic change appears gradual and continuous, without breaks or revolutions. Power figured in these models on several levels, as a leading technology driving the large cycle, and as an index of general business conditions. ${ }^{33}$

Two papers presented at the second World Power Conference in Berlin in 1930 picked up this latter idea and analysed the relation between power consumption and economic activity. As two delegates from the American Gas Association and the National Electric Light Association (NELA) plotted production statistics, to which they had access qua their organizational role, against prosperity (see Fig. 4). They concluded that "[e]lectricity has thus become the power medium of the nation and the central station plant the point of conversion of fuel and water into the country's major energy supply. (...) $[\mathrm{T}]$ he switchboard meters of these power houses have become, in effect, the pulses of the operation of the nation's industries to which their wires lead." Hugh Quigley, a member of the British Central Electricity Authority, conducted a comparative study of economic indices, concluding that electricity "is probably the best indicator of employment and industrial activity available in the countries where the degree of industrial electrification is very high." He admitted, however, that it

\footnotetext{
${ }^{30}$ Wright, Shin, \& Trentmann (2013); Russ (2020).

31 Barnes (1925, p. 1398), Hoover (1925, p. 1580).

32 Boianovsky \& Trautwein (2007, p. 489). This Swedish strand has often been overlooked in surveys of the literature. Wesley Clair Mitchell seemed to have learned of the Swedish works via a Russian paper summarised in French (!). While he was not able to read Enström, he "judge[s] Enström's investigations to merit more attention than they have received." (Mitchell 1927, p. 475)

33 Schumpeter's (1939) theory of business cycles combined both long-term (Kondratieff) waves and short term changes. See on business cycle research and its institutes, Özgöde (2015, 2020); Barnett (1995); Slobodian (2015). See for the discussion of business cycles in power development, Härry (1943).
} 
should not be used to make comparisons between countries whose economic structure was very different. $^{34}$

[Fig. 4: Ryan, P.; Carpenter, W. M. (1930): Methods of Collecting Power and Gas Statistics in the United States. In: World Power Conference (ed.): The Transactions of the Second World Power Conference. Vol. I: Uses of Electricity, Standardisation problems and the rationalization of statistics, Berlin: VDI Verlag, p. 361.]

The data of these industrial associations was limited to production of a certain form of energy. Due to its penetration of economic life, electricity was consumed in many other production processes. It was the energy form whose production reflected the general economic situation best. On the basis of data on electricity production published by the US Geological Survey, some banks developed 'business barometers'. Robert Davis, statistical editor of the journal Electrical World, had developed the regular business statistics on electricity into an index of industrial consumption in 1922. This work was later picked up by Frederic G. Tryon in his work an index of consumption of fuels and water-power. Tryon pioneered a cross-sectoral approach to energy in economics and went beyond the consumption of power to study "the contribution of this element of energy to wealth and production." 35 As an index of economic life and a factor of production, power was treated as a neutral medium whose flow recorded the state and growth of the economy.

The stream of information went not only from the electrical industry to economists, but also the other way around. Business barometers, such as Davis', had of course always targeted people working in the electrical industry. But knowledge of the larger cycles, the study of conjuncture, was helpful to orient engineers as well. This was an argument Axel Enström made in his article on trade cycles in the WPC's World Survey in 1935 (where he also claimed credit to have proven the long cycles long before Kondratiev and Wagemann verified them). Plotting power production of a Swedish power plant against time, he showed how future development could be extrapolated with regard to a larger cycle of technological saturation. "From comparisons with older processes of production, e.g., railway industry," he argued, "it may be concluded that a definite stage of saturation must be reached sooner or later, with the consequence that the development, in the very long run, will show a falling tendency." ${ }^{\prime 36}$ Here, electricity is likened to other great innovations, which all follow a similar s-shaped curve. The theory of large cycles contained the insight into the qualitative change brought about by technology, which had been expressed by $19^{\text {th }}$ century economic historiographies of progress and industrial revolution. At the same time, it restricted it to a cyclical phenomenon brought about by capitalism's ahistorical laws of appropriation. ${ }^{37}$

But historiographies of revolution and qualitative change were common in the industry as well. Rather than a neutral commodity recording the economy, power could also be seen as laying the ground for something entirely new. This perspective was strong at the early World Power Conferences. Hoover's statement of electricity as the 'greatest tool' reflected it, as well as Enström's 'Machine Power as a Cultural Factor' and the German engineer Franz zur Nedden's article on

\footnotetext{
34 Ryan \& Carpenter (1930, p. 364); Quigley (1930, p. 99).

35 Tryon (1927, p. 271-2), Missemer \& Nagaud (2020, pp. 2-3). Davis describes the making of his barometer in Electrical World (1922, pp. 939-40): Among the sectors of the power industry, only the light and power station business was capable of furnishing consumption statistics. For this reason, Davis constructed his barometer indirectly, through surveys in industries that are the prime outlet for the electrical industry: "The estimated horsepower of the motors installed in the plants of the various industries (...) has been taken as the basis for weighting the industries.” (1922, p. 940)

36 Enström (1935, p. 9).

${ }^{37}$ See for this also Trotsky's arguments against Kondratiev’s long waves, Day 1976.
} 
'Power's Service to the World', to name but a few. ${ }^{38}$ The main idea was that electrical power remade the forces and relations of production in a way that a new kind of economy-planned, national, or socialist-became a possibility. This perspective was widely shared among progressive engineers with a program of social reform, but it could also be found among Europe's liberal or nationalist elites who sought ways to ground their projects of technological internationalism or national autarky. ${ }^{39}$

Unlike the earlier evolutionary energetics of Patrick Geddes or Wilhelm Ostwald, these interwar thinkers focused on the practical significance of electrification in remaking the national economy. Electrification appeared here as a force of rationalization that allowed a higher degree of autarky and the reduction of human labour. The large, monopolistic corporations, common in the fuel and power industry, served as a model of how an economy could be organised. ${ }^{40}$ Walther Rathenau, by then minister of foreign affairs of the young Weimar Republic, praised electrification as a force of economic rationalization since the turn of the century. In the near future "mechanical power will have risen to such an extent," he claimed in his vision of a planned economy 'The New Society', "that it would bear any relief of human power." This vision of abundance stood in striking contrast to Germany's economic deprivation after the war. But Rathenau was not alone in this assessment. Carl Ballod's Zukunftsstaat (State of the Future) had struck a similar note already in 1898, emphasising even more the leisure that could already be achieved at the level of the contemporary productive forces.

This quantitative argument about autarky and labour reduction rested on a qualitative difference electric power made - in the view of these engineers it was not just more of the old steam power, it was an entirely different form of energy. The electrical systems deemed the most progressive at that time were power systems: interconnected grids spanning a couple of hundred kilometres, integrating several power plants and covering a wide range of consumers. In comparison to the steam economy, these systems centralised and coordinated the supply of a form of energy, which was so versatile that it could be used for all kinds of economic activities. Drawing on Ballod and Lenin's idea of the Socialist economy as a single factory, the Soviet economist Iosif Ivanov envisioned a general economic coordination through centralised power supply. ${ }^{41}$ What is more, these power systems worked on the basis of a complementary principle. Interconnected systems promised to overcome the social and geographic diversity of modern states, they could supply workers' households because they supplied the industry and constituted a "seamless web: the unity of land and water and men," as David Lilienthal later put it. ${ }^{42}$ All sufficiently diverse systems could be rationalized in this way. In this spirit, the German engineer Oskar Oliven presented a plan to interconnect Europe in a single grid on the second World Power Conference. The utopia of a technological reconciliation of city and countryside, capital and labour, nature and culture, was articulated in many large-scale electrification projects at that time. ${ }^{43}$

Nowhere was this difference of electricity brought into sharper relief with the world economic order than in the Soviet Union. Since the early 1920s, Soviet economic planning had mainly developed around the electrification plan and, in turn, electrification was seen as the 'technical-economic basis' of the socialist economy. In the view of Soviet energy engineers, electrification had developed within

38 Enström (1930), zur Nedden (1935).

39 Steinmetz (1916), Quigley (1925), Henderson (1931).

40 Bockman (2011, pp. 30-1).

${ }^{41}$ Rathenau (1919, p. 363), Ballod (1919, p. 226), Ivanov (1923). Ballod's book was republished twice in 1919 and 1920 , Balabkins (1978).

42 Lilienthal (1944, p. 58).

${ }^{43}$ Krzhizhanovskii (1928), Oliven (1930), Lagendijk (2012, 2009, pp. 69-90). 
capitalism, but it contained in itself the possibility for overcoming it - the concentration and socialisation of power. Veniamin Veic, a young engineer-economist at the Communist Academy of Science, articulated this thought in his paper 'The Energy Problem in the Current World Economy' at the second World Power Conference in Berlin in 1930. Here, Veic painted a history of the productive forces and their energy basis that culminated in regional power stations. In line with the reinterpretations of the industrial revolution at that time, ${ }^{44}$ he argued that the energy basis had always constituted the critical problem in the transition between economic periods. In his view, in the postwar time, the contradiction consisted of a technical system that allowed for central control and a relocation of industrial centres, and a social system that clung to the private management of the capital concentrated in cities. ${ }^{45}$

Attacking the capitalist countries head-on, Veic's paper was quietly ignored during the discussion. Yet a second Soviet paper, no less rooted in Soviet energetic thinking, was widely welcomed. Maria Falkner-Smit, one of Veic's colleagues in the Communist Academy of Sciences, presented her research on what she called the 'energification' of industry - the analysis of the relation between electrification, productivity, and wages. If such a relation existed, the application of electricity in production could rightly stand for the general economic progress. ${ }^{46}$ Similar to Tryon and others, Falkner-Smit was interested in how energy created value. Like other Bolshevik engineers and economists of that time, Falkner-Smit argued for the creation of an economy based on an energetic value form, an economy in which wages would reflect the amount of 'horse-power hours' commanded per worker. This would ultimately mean to dethrone money as unit of accounting and economic planning, as the head of the State Planning commission, Gleb M. Krzhizhanovskii, argued. Someday, the economic plan would "be replaced by a red book, showing what the worker would accomplish and receive, a blue book showing the energy plan (...), and a yellow book presenting the plan in money terms." 47

For all the differences in economic world views, the calculations around power systems served as a point of reference across the political spectrum; the language of energy and power constituted a political lingua franca at the World Power Conferences. As Carl Schmitt noted, both Lenin and the industrialist share the ideal of an 'electrified earth'. ${ }^{48}$ Electricity automized energy supply to a certain extent: By removing steam engines and the open fire from the everyday experience of many people, energy has in a certain sense become less visible. At the same time, however, energy gripped the public imagination, it was prevalent in the politics, utopias and fears of the time. As attempts to institutionalize energy economics, or to create a more harmonious, moneyless economy, the abovementioned projects have failed: Tryon's work was only rediscovered in the 1970s, when the relation between energy and growth became problematic; Rathenau was murdered too early to personally influence interwar economic policy; and the Soviet energy engineers lost their influence on planning when Stalin secured his power in the 1930s. Still, their attempts were documented in books and articles, and some of their projects have been picked up and realized at a later point in time (such as Oliven's all-European power grid).

\section{Conclusion}

\footnotetext{
${ }^{44}$ Cf. Henderson (1931, p. 15).

45 Veic (1930), see for an introduction to Soviet energetics Russ (2021). The Communist Academy of Science was the competitor organization to the traditional Russian Academy of Science and an institution that focused more on social sciences, economics, engineering and other applied sciences.

${ }^{46}$ Falkner-Smit (1930).

${ }^{47}$ Krzhizhanovskii cited in Davies (1998, p. 175).

48 Schmitt (2019, p. 22).
} 
This paper has argued that the power economy is a distinct economic and political appropriation of electricity in the interwar years. For a short period, the power economy assumed this broader meaning of conditioning and representing economic life. Engineers tried to use electricity to record the entire economy and visualise its state of economic development. Penetrating an ever-greater part of economic life and constituting a key technology of future industrialization, electricity seemed a commodity that was general and quantifiable enough to compete against money. This view was particularly strong among critiques of market economies and liberal economics: technocrats, socialists, and economic nationalists and imperialists. However, given the currency crises and the role of financing in electrical development in the interwar period, it should not be surprising that contemporaries outside (and even inside) the electro-technical industry were not satisfied by a mode of representation of the economy which neglected monetary flows entirely. Even the Soviet engineers had to take material and cost efficiency into account. In business circles research and the indicators that sprang from it, electricity makes only for one of several crucial economic sectors.

The power economy yields a different, but no less limited representation of economic life than the monetary economy. The technical, economic and political limits of power systems determine whose demand and which supply can become part of the power economy. The power economy documents only commercially produced energy: Unlike the eighteenth-century economy of nature and the nineteenth-century economy of work, human beings are no longer a part of the twentieth-century power economy. ${ }^{49}$ This is not to say that workers no longer toiled in mines, but that their labour did not appear in the statistics of the power economy. This new relation is best captured in the ratio of power per person, a widely used indicator of economic backwardness at the time. ${ }^{50}$ The working population commands and consumes this power, but its own work does not add to it. But not everyone was included as consumers either: in colonial contexts, electrification was more often restricted to industry and rural areas were generally more difficult to connect on the basis of principles developed in the urban economy. For all these omissions, power economies were imagined as structurally similar, national spheres of energy flows, which together make up the world power economy.

Rather than replacing general economic theory, thinkers of the power economy made pioneering contributions to development and energy economics. The business indicators put together by industry journals and associations were the basis of Tryon's work on the relationship between energy and growth in the Brookings Institution. Similarly, Falkner-Smit's research on 'energification' in the Communist Academy of Science established the link between energy use and productivity the Soviet model of development built on. While Tryon tried to discern that part of economic growth which hinged on energy use, Falkner-Smit was more interested in the effect of energy use on different industrial sectors. In their different ways, both conceptualised not only the positive relation between energy and growth or productivity, but also its limits. Falkner-Smit found, for instance, that the simple relation between energy use, productivity, and wages, existed only in the heavy industry.

Today, we speak about the 'energy economy' rather than the 'power economy' or 'Kraftwirtschaft, as it was rendered in German. From the 1950s onwards, the term 'power' was gradually replaced by 'energy' in the languages that make this difference (in the Romanic and Slavic languages, the 'power' in World Power Conference had always been translated as 'energy'). 'Power' still conveyed its roots

\footnotetext{
49 Schabas (2005), Rabinbach (1990).

50 This indicator figured prominently in the first Five-Year-Plan of the Soviet Union (Russ 2021) and, as Liz Chatterjee has pointed out, in the electrification of India.
} 
in mechanics and electrical engineering-fields the existing energy economy had long outgrown: not the power of machinery, but the substitutions and transformations of energy became the leading metaphor. This focus on energy accounting led to a rather de-materialised energy economics, even among Socialist energy economists. The reintroduction of the concept of matter by ecological economists such as Georgescu-Roegen in the 1970s did not make it into energy economics and the industrial discourse at large.

Occasionally, economists still use power to gauge real economic activity beyond the GDP - an indicator that always follows behind economic activity and that hinges on a large statistical infrastructure. The intensity of night-time electric light seen from space has been proposed "as a proxy for economic activity or economic development" in regions "where disaggregated data from statistical offices are not available. ${ }^{\text {c51 }}$ Nocturnal luminosity has also been used as a source of information on regions or countries that do not publish reliable economic data, such as North Korea. ${ }^{52}$ Electricity data can also give an early hint of the depth of an economic crisis: The economic impact of the lockdown due to the Covid-19 epidemic appeared immediately on the records of power stations. Economists used this data on shrinking electricity consumption to compare the relative decline of economic activity over countries. ${ }^{53}$ Recording economic activity in real time and without much statistical effort, electricity continues to be a source of economic information. Today, however, these numbers are seen as representing what is, they no longer foretell an economic future.

51 Bruederle \& Hodler (2018).

52 Henderson, Storeygard, \& Weil (2012); The Economist (2019, May 4), Satellite Data shed new light on North Koreas opaque economy. Retrieved from: https://www.economist.com/graphic-detail/2019/05/04/satellite-data-shed-newlight-on-north-koreas-opaque-economy.

53 McWilliams \& Zachmann (2020), Bruegel electricity tracker of COVID-19 lockdown effects, Bruegel Datasets, first published 25 March. Retrieved from https://www.bruegel.org/2020/03/covid-19-crisis-electricity-demand-as-a-realtime-indicator/. 


\section{References}

Akin, W. E. (1977). Technocracy and the American Dream: The Technocrat Movement, 1900-1941. Berkeley, CA: University of California Press.

Bachelard, G. (1986). The New Scientific Spirit. Boston, MA: Beacon Press.

Balabkins, N. W. (1978). Der Zukunftsstaat: Carl Ballod's Vision of a Leisure-Oriented Socialism. History of Political Economy 10, 2, 213-232.

Ballod, C. (1919). Der Zukunftsstaat: Produktion und Konsum im Sozialstaat. Stuttgart: Dietz.

Barnes, J. H. (1925). Power Development in Relation to Human Progress. In The World Power

Conference (ed.), The Transactions of the First World Power Conference (pp. 1398-1405). London: P. Lund, Humphries \& Co.

Barnett, V. (1995). A Long Wave Goodbye: Kondrat'ev and the Conjuncture Institute, 1920-28. Europe-Asia Studies, 47, 3, 413-441.

Bockman, J. (2011). Markets in the Name of Socialism: The Left-Wing Origins of Neoliberalism. Stanford, CA: Stanford University Press.

Boianovsky, Mauro, \& Trautwein, Hans-Michael (2007). Johan Åkerman vs. Ragnar Frisch on Quantitative Business Cycle Analysis. The European Journal of the History of Economic Thought, 14, 3, 487517.

Bruederle, A. \& Hodler, R. (2018). Nighttime Lights as a Proxy for Human Development at the Local Level. PLOS ONE 13 (9): e0202231. URL: https://doi.org/10.1371/journal.pone.0202231. Büthe, T. (2010). Engineering Uncontestedness? The Origins and Institutional Development of the International Electrotechnical Commission (IEC). Business and Politics, 12(3), 1-62.

Cassirer, E. (1953). Substance and Function and Einstein's Theory of Relativity. New York, NY: Dover Publications.

Chandler, A. D. (2002). The Visible Hand: The Managerial Revolution in American Business. Cambridge, MA: Harvard University Press.

Coopersmith, J. (1992). The Electrification of Russia, 1880-1926. Ithaca, NY: Cornell University Press.

Coopersmith, J. (1993). Soviet electrification: The roads not taken. IEEE Technology and Society

Magazine, 12(2), 13-20.

Coopersmith, J. (2004). When Worlds Collide: Government and Electrification, 1892-1939. Business

and Economic History On-Line, 1, 1-31.

Cravath, J. R. (1915). Demand and Diversity Factors and their Influence on Rates (1910) (Edison Illuminating Company, Ed.; pp. 101-114). Detroit: The Edison Illuminating Company of Detroit.

Davies, R. W. (1998). The Soviet Economy in Turmoil, 1929-1930. Basingstoke: Macmillan Press.

Day, R. (1976). The Theory of Long Waves: Kondratiev, Trotsky, Mandel. New Left Review 99, 67-82. Deltete, R. J. (2005). Die Lehre von der Energie: Georg Helm’s Energetic Manifesto. Centaurus, 47, 2 , 140-162.

Deltete, R. J. (2006). Wilhelm Ostwald's Energetics 1: Origins and Motivations. Foundations of Chemistry, 9, 1, 3.

Deltete, R. J.(2007). Wilhelm Ostwald's energetics 2: Energetic theory and applications, part I. Foundations of Chemistry, 9, 3, 265.

Deltete, R. J. (2008). Wilhelm Ostwald's energetics 3: Energetic theory and applications, part II. Foundations of Chemistry, 10, 3, 187.

Enström, A. (1935). The Future Development of Power Producing Industries. World Survey, 1, 1, 8-9. Falkner-Smit, M. (1930). The Motor Power Outfit of Labour and Its Economic Efficiency. In The Transactions of the Second World Power Conference. Band XVI: World Problems of Power Economics (pp. 60-71). Berlin: VDI Verlag, 60-71.

Forbes, G. (1889). Some electric lighting central stations in Europe, and their lessons. Journal of the Institution of Electrical Engineers, 18, 78, 161-197. 
Gilson, N. (1996). Die Vision der Einheit als Strategie der Krisenbewältigung? Georg Klingenbergs Konzeption für die Energieversorgung in Deutschland zu Beginn des 20. Jahrhunderts. In H.-L. Dienel (Ed.), Der Optimismus der Ingenieure (pp. 57-76). Stuttgart: F. Steiner.

Haas, R. (1895). Die Berechnung der Abschreibung von Elektrizitätskraftwerken. Elektrotechnische Zeitschrift, 8, 121-122.

Hannah, L. (1979). Electricity before Nationalisation: A Study of the Development of the Electricity Supply Industry in Britain to 1948. London: MacMillan.

Hannah, L., Millward, R., \& Singleton, J. (1995). The Political Economy of Nationalisation in Britain, 1920-1950. The Economic History Review, 48(4), 833.

Härry, A. (1943). Einige Probleme der Oekonomik der Wasserkraftnutzung, insbesondere die Produktion und die Verteilung. Dissertation at the Universität Zürich.

Hausman, W. J., Hertner, P., \& Wilkins, M. (2008). Global Electrification Multinational Enterprise and International Finance in the History of Light and Power, 1878-2007. Cambridge: Cambridge University Press.

Hawley, E. W. (1966). The New Deal and the Problem of Monopoly. Princeton, NJ: Princeton University Press.

Heilbron, J. L. (1982). Elements of Early Modern Physics. Berkeley, CA: University of California Press. Henderson, F. (1931). The Economic Consequences of Power Production. London: G. Allen \& Unwin, Limited.

Henderson, J. V., Storeygard, A., \& Weil, D. N. (2012). Measuring Economic Growth from Outer Space. The American Economic Review, 102, 2, 994-1028.

Hopkinson, J. (1915). On the cost of Electric Supply (1892). In Edison Illuminating Company (Ed.), The Development of scientific rates for electricity supply; being reprints of selected original rate papers (pp. 5-20).

Detroit, MI: The Edison Illuminating Company of Detroit.

Hoover, H. (1925). Government policies in relation to power development and distribution. In World Power Conference (Ed.), The Transactions of the first World Power Conference, Vol V (pp. 15801590). London: P. Lund, Humphries \& Co., Ltd.

Hughes, T. P. (1976). Technology and public policy: The failure of giant power. Proceedings of the IEEE, 64, 9, 1361-1371.

Hughes, T. P. (1979). The Electrification of America: The System Builders. Technology and Culture, 20, 1, 124-161.

Hughes, T. P. (1987). The Evolution of Large Technological Systems. In W. E. Bijker, T. P. Hughes, \& T. J. Pinch (Eds.), The Social Construction of Technological Systems. New Directions in the Sociology and History of Technology (pp. 51-82). Cambridge, MA: MIT Press.

Hughes, T. P. (1993). Networks of Power: Electrification in Western Society, 1880-1930. Baltimore, ML: Johns Hopkins University Press.

Insull, S., \& Keily, W. E. (1915). Central-station electric service; its commercial development and economic significance as set forth in the public addresses (1897-1914) of Samuel Insull. Chicago, IL: privately printed. Ivanov, I. (1923): Materialnyi Bazis Kommunisticheskogo Obshchestva. Vestnik Socialisticheskoi Akademii, 4, pp. 169-185.

Joll, James. 1960. Intellectuals in Politics: Three Biographical Essays. London: Weidenfeld and Nicolson. Klingenberg, G. (1913). Bau großer Elektrizitätskraftwerke. Erster Band: Richtlinien für den Bau großer Elektrizitätswerke. Berlin: Julius Springer.

Klingenberg, G. (1914). Bau großer Elektrizitätskraftwerke. Zweiter Band: Verteilung elektrischer Arbeit über große Gebiete. Berlin: Julius Springer.

Klingenberg, G. (1920). Bau großer Elektrizitätskraftwerke. Dritter Band: Das Kraftwerk Golpa. Berlin: Julius Springer.

Lambert, J. D. (2015). The Power Brokers: The Struggle to Shape and Control the Electric Power Industry.

Cambridge, MA: MIT Press. 
Lilienthal, D. E. (1944). TV A: Democracy on the March. New York: Harper and Bros. Pub. Lagendijk, V. (2009). Electrifying Europe: The Power of Europe in the Construction of Electricity Networks. Amsterdam: Aksant Academic Publishers Transaction Publishers.

Lagendijk, V. (2012). 'To Consolidate Peace'? The International Electro-Technical Community and the Grid for the United States of Europe. Journal of Contemporary History, 47, 2, 402-426.

McWilliams, B. \& Zachmann, G. (2020). Bruegel electricity tracker of COVID-19 lockdown effects, Bruegel Datasets, first published 25 March. Retrieved from https://www.bruegel.org/2020/03/covid-19-crisis-electricity-demand-as-a-real-time-indicator/ Meer, E. van. (2012). The Transatlantic Pursuit of a World Engineering Federation: For the Profession, the Nation, and International Peace, 1918-48. Technology and Culture, 53, 1, 120-145.

Merz, C. H., \& McLellan, W. (1904). Power station design. Journal of the Institution of Electrical Engineers, 33, 167, 696-742.

Meyer, M. (1895). Die Entwicklung der städtischen Elektrizitätswerke. Elektrotechnische Zeitschrift, 2, 26.

Miller, O. von (1906). Die Entwicklung Der Elektrotechnik. Gaea. Natur und Leben, XXXXII, X, 610 611.

Missemer, A., \& Nadaud, F. (2020). Energy as a Factor of Production: Historical Roots in the American Institutionalist Context. Energy Economics, 86, pp. 1-11.

Mitchell, W. C. 1927. Business Cycles: The Problem and Its Setting. New York City, NY: National Bureau of Economic Research.

Mitchell, T. (2002). Rule of Experts: Egypt, Techno-Politics, Modernity. Berkeley, CA: University of California Press.

Müllendorf, A. (1894). Ueber die Beurtheilung der Rentabilität elektrischer Anlagen. Polytechnisches Journal, 292, 110-112.

Oliven, Oskar (1930): "Europas Großkraftlinien. Vorschlag eines europäischen Hochspannungsnetzes." In: Transactions of the Second World Power Conference, Vol. XIX, Berlin: VDI Verlag.

Özgöde, O. (2015). Governing the Economy at the Limits of Neoliberalism: The Genealogy of Systemic Risk Regulation in the United States, 1922-2012. Dissertation at Columbia University. Özgöde, O. (2020). Institutionalism in Action: Balancing the Substantive Imbalances of "the Economy" through the Veil of Money. History of Political Economy, 52, 2, 307-339.

Paquier, S. (2001). Swiss holding companies from the mid-nineteenth century to the early 1930s: The forerunners and subsequent waves of creations. Financial History Review, 8, 2, 163-182.

Passer, H. C. (1953). The Electrical Manufacturers, 1875-1900. A Study in Competition, Entrepreneurship, Technical Change, and Economic Growth. Cambridge, MA: Harvard University Press.

Pinner, F. (1918). Emil Rathenau und das elektrische Zeitalter. Leipzig: Akademische Verlagsgesellschaft. Platt, Harold L. (1991). The Electric City: Energy and the Growth of the Chicago Area, 1880-1930. Chicago: University of Chicago Press.

Quigley, H. (1925). Electrical Power and National Progress. London: G. Allen \& Unwin.

Quigley, H. (1930). Electricity as an Index of lndustrial Production and Employment. In The

Transactions of the Second World Power Conference. Vol. XVI: World Problems of Power Economics (pp. 95127). Berlin: VDI Verlag.

Rabinbach, A. (1990). The Human Motor: Energy, Fatigue, and the Origins of Modernity. New York: Basic

Books.

Rathenau, W. (1919). Die Neue Gesellschaft. Berlin: S. Fischer.

Rheinberger, H.-J. (2005). Gaston Bachelard and the Notion of "Phénomenotechnique". Perspectives on Science, 13, 3, 313-328.

Russ, D. (2020). Speaking for the 'world power economy': Electricity, energo-materialist economics, and the World Energy Council (1924-78). Journal of Global History, 15, 2, 311-329. 
Russ, D. (2021). Energetika: Gleb M. Krzhizhanovskii's Conception of the Nature-Society Metabolism. Historical Materialism, 29, 2.

Russ, D. \& Turnbull, T. (2021): Competing Powers: Engineers, Energetic Productivism, and the End of Empire. In D. Russ \& J. Stafford (eds.), Competition in World Politics (pp. 183-210), Bielefeld: transcript.

Ryan, P. \& W. M. Carpenter (1930): Methods of Collecting Power and Gas Statistics in the United States. In The Transactions of the Second World Power Conference. Vol. I: Uses of Electricity, Standardisation problems and the rationalization of statistics (pp. 357-365), Berlin: VDI Verlag. Schabas, M. (2005). The Natural Origins of Economics. Chicago, IL: University of Chicago Press. Schilling, D. (1883). Bemerkungen Über Das Elektrische Licht. Gaea. Natur und Leben, 19, 230-239. Schmitt, C. (2019). Römischer Katholizismus und politische Form. Stuttgart: Klett-Cotta.

Schumpeter, J. A. (1939). Business Cycles: A Theoretical, Historical, and Statistical Analysis of the Capitalist Process. New York City, NY: McGraw-Hill.

Segreto, L. (1994). Financing the Electric Industry Worldwide: Strategy and Structure of the Swiss Electric Holding Companies, 1895-1945. Business and Economic History, 23, 1, 162-175.

Siegel, G. (1906). Die Preisstellung beim Verkaufe elektrischer Energie. Berlin: Springer.

Slobodian, Q. (2015). How to see the world economy: Statistics, maps, and Schumpeter's camera in the first age of globalization. Journal of Global History, 10, 2, 307-332.

Smith, C. (1998). The Science of Energy: A Cultural History of Energy Physics in Victorian Britain. Chicago, IL: University of Chicago Press.

Stabile, D. R. (1986). Veblen and the Political Economy of the Engineer: The Radical Thinker and Engineering Leaders Came to Technocratic Ideas at the Same Time. The American Journal of Economics and Sociology, 45, 1, 41-52.

Stapleford, T. A. (2018). Historical Epistemology and the History of Economics: Views Through the Lens of Practice. In T. Düppe \& H. Maas (Eds.), Historical Epistemology of Economics (pp. 113-145).

Emerals Publishing Limited.

Steinmetz, C. P. (1916). America and the New Epoch. New York, London: Harper \& Brothers

Publishers.

Stichweh, R. (1988). Technologie, Naturwissenschaft und die Struktur wissenschaftlicher

Gemeinschaften: Wissenschaftliche Instrumente und die Entwicklung der Elektrizitätslehre. Kölner Zeitschrift für Soziologie und Sozialpsychologie, 40, 4, 684-705.

Stier, B. (1999). Staat und Strom: die politische Steuerung des Elektrizitätssystems in Deutschland 1890 - 1950. Ubstadt-Weiher: Verlag Regionalkultur.

Tooze, J. A. (2015). The Deluge: The Great War, America and the Remaking of Global Order, 1916-1931. London: Penguin.

Tripp, G. E. (1925). The Relation of Power Development to Industrial and Economic Progress. In World Power Conference (Ed.), The Transactions of the First World Power Conference, Vol. IV (pp. 14461455). London: P. Lund, Humphries \& Co., Ltd.

Tryon, F. G. (1927). An Index of Consumption of Fuels and Water Power. Journal of the American Statistical Association, 22, 159, 271-282.

Veic, V. I. (1930). Das Energieproblem in der gegenwärtigen Weltwirtschaft. In The Transactions of the Second World Power Conference in Berlin, 1930, Band XVI: General Problems of the Power Economy and Legal Problems (pp. 72-94). Berlin: VDI Verlag.

Wilke, A. (1893). Die Elektrizität, ihre Eræeugung und ibre Anwendung in Industrie und Gewerbe. Berlin: Springer.

Wright, R., Shin, H., \& Trentmann, F. (2013). From World Power Conference to World Energy Council: 90 Years of Energy Cooperation, 1923-2013. London: World Energy Council. 